\title{
FRESHLY ISOLATED HEPATOCYTE TRANSPLANTATION IN ACETAMINOPHEN-INDUCED HEPATOTOXICITY MODEL IN RATS
}

\author{
Daniela RODRIGUES ${ }^{1,2}$, Themis Reverbel da SILVEIRA ${ }^{1,3}$, Ursula MATTEE, 4, 5; \\ The Study Group on Experimental Hepatology
}

\begin{abstract}
Context - Hepatocyte transplantation is an attractive therapeutic modality for liver disease as an alternative for orthotopic liver transplantation. Objective - The aim of the current study was to investigate the feasibility of freshly isolated rat hepatocyte transplantation in acetaminophen-induced hepatotoxicity model. Methods - Hepatocytes were isolated from male Wistar rats and transplanted 24 hours after acetaminophen administration in female recipients. Female rats received either $1 \times 10^{7}$ hepatocytes or phosphate buffered saline through the portal vein or into the spleen and were sacrificed after 48 hours. Results - Alanine aminotransferase levels measured within the experiment did not differ between groups at any time point. Molecular analysis and histology showed presence of hepatocytes in liver of transplanted animals injected either through portal vein or spleen. Conclusion - These data demonstrate the feasibility and efficacy of hepatocyte transplantation in the liver or spleen in a mild acetaminophen-induced hepatotoxicity model.
\end{abstract}

HEADINGS - Hepatocytes, transplantation. Acetaminophen. Drug-induced liver injury. Rats.

\section{INTRODUCTION}

Orthotopic liver transplantation (OLT) has emerged as an effective treatment for acute liver failure (ALF) and end-stage liver disease. However, wider application of this therapy is limited primarily by lack of donors. Therefore other liver support systems, such as extracorporeal systems and cellular therapy are under evaluation ${ }^{(18,19,24)}$.

Hepatocyte transplantation has been used as a treatment for liver-based metabolic diseases such as Crigler-Najjar syndrome type $\mathrm{I}^{(7)}$, glycogen storage disease type $1 \mathrm{a}^{(15)}$, urea cycle defects ${ }^{(9,14)}$ and congenital deficiency of coagulation factor VII ${ }^{(5)}$. For ALF, hepatocyte transplantation can be used to bridge patients to whole-organ transplantation, decreasing mortality and avoiding the risks of undertaking a major surgery ${ }^{(6,17)}$. Up to a maximum of $5 \%$ of normal liver mass can be transplanted into the splenic artery or the portal vein, leading to a reduction in ammonia, bilirubin levels and improvement in hepatic encephalopathy ${ }^{(27)}$.

Acetaminophen (APAP) toxicity is the leading cause of ALF in the United States and United Kingdom, accounting for $46 \%$ and $70 \%$ of cases, respec- tively $(12,24)$. The mechanism of liver toxicity is well established. The saturation of the normal metabolic pathway to cytochrome P450 metabolism leads to the excessive formation of highly reactive intermediate N-acetyl-p-benzoquinone imine (NAPQI). At therapeutic doses, NAPQI is efficiently detoxified by gluthatione (GSH). In overdose, conjugation of NAPQI with GSH leads to GSH depletion, and NAPQI covalently binds to cysteine residue in proteins to form APAP adducts. These protein adducts are formed from highly reactive species of superoxide and nitric oxide and that increases the permeability of mitochondrial membrane with release of superoxide of the mitochondria, a lethal event for the cell ${ }^{(11,21)}$.

In the present study, the feasibility of freshly isolated rat hepatocyte transplantation in APAP-induced hepatotoxicity model either injected through the portal vein or into the spleen was investigated.

\section{METHODS}

\section{Animals}

Male and female Wistar rats at least 8-week-old were kept at Experimental Animal Unit of Research

\footnotetext{
The present study was performed at Experimental Hepatology and Gastroenterology Laboratory and Gene Therapy Center, Hospital de Clínicas, Porto Alegre, RS, Brazil. 'Experimental Hepatology and Gastroenterology Laboratory, Hospital de Clínicas de Porto Alegre; ${ }^{2}$ Post Graduation Program: Sciences in Gastroenterology, Faculdade de Medicina, Universidade Federal do Rio Grande do Sul (UFRGS); ${ }^{3}$ Post Graduation Program in Adolescent and Child Health, UFRGS; 4 Post Graduation Program in Genetics and Molecular Biology, UFRGS: ${ }^{5}$ Gene Therapy Center, Hospital de Clínicas de Porto Alegre, RS, Brazil.

The Study Group on Experimental Hepatology: Rafael Lucyk Maurer, Carolina Uribe Cruz, Alvaro Macedo Laureano, Nelson Alexandre Kretzmann, Gabriella Rejane dos Santos. Correspondence: Prof. Ursula Matte - Gene Therapy Center - Rua Ramiro Barcelos, 2350 - 90035-903 - Porto Alegre, RS, Brazil. E-mail: umatte@hcpa.ufrgs.br
} 
Center of Hospital de Clínicas de Porto Alegre (UEA-HCPA), Porto Alegre, RS, Brazil, under controlled temperature (between $18^{\circ} \mathrm{C}$ and $22^{\circ} \mathrm{C}$ ) in 12 -h light-dark cycle. Rats were given standard laboratory rodent chow and water ad libitum. Male rats were used as hepatocyte donors and female rats were used as recipients.

This study was approved by Research and Ethics Committee of HCPA and all procedures were in accordance with Brazilian Law 11794 and Act 6899 of July 15, 2009, that encompasses Brazilian regulation regarding the use of animals for scientific research.

\section{APAP-induced hepatotoxicity model}

The APAP-induced hepatotoxicity model was adapted from Salam et al. ${ }^{(24)}$. An oral solution of APAP at $200 \mathrm{mg} / \mathrm{mL}$ concentration (Medley, Brazil) was administered in a single dose of $1 \mathrm{~g} / \mathrm{kg}$ via intraperitoneal injection in female rats weighing 200-350 g. Four days before the intraperitoneal injection, animals received phenobarbital (Fenocrisis 4\%, Brazil) at $350 \mathrm{mg} / \mathrm{L}$ in drinking water to induce cytochrome P-450 enzymes to potentiate subsequent APAP-toxicity ${ }^{(2)}$. Phenobarbital was offered until the last day of the study (day 3). Animals were euthanized at day 3 after APAP administration.

\section{Hepatocyte isolation}

Hepatocytes were isolated from male rats weighing 350$500 \mathrm{~g}$ by perfusion of liver with modified two-step collagenase technique ${ }^{(25)}$. In the first step, portal vein was cannulated and inferior vena cava was opened to remove blood with HBSS medium without calcium, magnesium and phenol red (LGC Biotecnologia, Brazil) and EDTA (Nuclear, Brazil) with a $700 \mathrm{~mL} / \mathrm{h}$ flow controlled by pump infusion. In the second step, superior vena cava was cannulated and inferior vena cava was clamped for perfusion with HBSS medium, $1 \mathrm{M}$ calcium chloride (Vetec, Brazil) and type II collagenase 2\% (Gibco, Invitrogen Corporation, USA). Penicillin/streptomycin $1 \%$ (Gibco, Invitrogen, USA) was added to all of the above solutions.

Liver fragments obtained were kept in HBSS medium and 10\% antibiotics and taken to a laminar flow hood. The fragments were transferred to vials with HBSS medium and decreasing $5 \%$ to $2 \%$ antibiotics solution. Liver sections were minced and the cell suspension was passed through a gauze mesh, centrifuged 3 times at $800 \mathrm{rpm}$ for 5 minutes and washed in HBSS medium 3 times. In the last washing, hepatocytes were resuspended in phosphate buffered saline (PBS), (Laborclin, Brazil) and cell viability was determined by trypan's blue exclusion.

In a subgroup of 11 randomly chosen animals, cells were stained prior to injection with DAPI (4', 6-diamidino-2-phenylindole, Roche Mannheim, Germany) $2.7 \mathrm{mg} / \mathrm{mL}$ to assess the migration pattern of donor hepatocytes according to the different sites of injection (portal vein or spleen) $)^{(3)}$.

\section{Hepatocyte transplantation}

Hepatocytes $\left(1 \times 10^{7}\right)$ were administered 24 hours after APAP-induced hepatotoxicity in female rats. Animals were anesthetized with $50 \mathrm{mg} / \mathrm{kg}$ of ketamine (Dopalen, Vetbrands, Brazil) and $20 \mathrm{mg} / \mathrm{kg}$ of xilazine (Virbaxyl $2 \%$, Virbac, Brazil) intraperitoneally.

Forty-four female rats were separated in four groups: group PV-H received hepatocyte transplantation through the portal vein $(\mathrm{n}=8)$, group PV-PBS received PBS through the portal vein $(n=15)$, group SPL-H received hepatocyte transplantation into the spleen $(\mathrm{n}=12)$, and group SPL-PBS received PBS into the spleen $(n=9)$. In animals that received the injection into the portal vein, a longitudinal $3 \mathrm{~cm}$ abdominal incision was performed, and a volume of $1 \mathrm{~mL}$ of PBS (containing or not $1 \times 10^{7}$ hepatocytes) was slowly injected into the portal vein. Gelfoam (Cuntanplast, Mascia Brunelli Spa, Milano, Italy) was applied to the site of injection in order to avoid bleeding. In animals that received injection into the spleen, a vertical $2 \mathrm{~cm}$ abdominal incision below left costal edge was performed and the spleen was exposed. A volume of $1 \mathrm{~mL}$ of PBS (containing or not-hepatocytes) was slowly injected into the spleen pulp. Rats were sutured in layers with polyglactine 4-0 (Vycril Ethicon, São Paulo, Brazil) and in the skin with mononylon 4-0 (Monocryl Ethicon, São Paulo, Brazil). Animals recovered in the cage.

\section{Biochemistry}

Blood was collected at time point 0 (before APAP administration), and at days 1 and 3 after APAP administration through retrorbital punction under anesthesia. Samples for alanine aminotransferase (ALT) were centrifuged at 4000 $\mathrm{rpm}$ for 5 minutes, and stored at $-20^{\circ} \mathrm{C}$. ALT was measured using ultraviolet enzyme method at Roche/Hitachi ACN 685 E equipment.

\section{Histology}

Animals that survived until day 3 were sacrificed in $\mathrm{CO}_{2}$ chamber. Liver and spleen samples were collected and placed in $10 \%$ buffered formalin solution for 24 hours. Unstained paraffin embedded sections were observed under fluorescent microscopy and the number of DAPI-positive cells was counted in 100 high power fields. In addition, spleen slides were stained with $\mathrm{H}-\mathrm{E}$ to visualize injected hepatocytes.

\section{Molecular analysis}

To detect the presence of donor cells, DNA was extracted with Trizol (Invitrogen, USA) from liver and spleen samples and PCR for Sry gene was performed using the following primers at $50^{\circ} \mathrm{C}$ (for 5' AAGCGCCCCATGAATGCATT 3', rev 5' CAGCTGCTTGCTGATCTCTG 3'). PCR products were visualized in $1.5 \%$ agarose gels stained with ethidium bromide ${ }^{(1)}$.

In a subgroup of eight animals from group SPL-H spleen samples were snap-frozen in liquid nitrogen and stored at $-80^{\circ} \mathrm{C}$ to perform reverse-transcriptase polymerase chain reaction (RT-PCR) for albumin expression. Total RNA was extracted using a commercial kit (Easy RNA, Qiagen, Germany) following the manufacturer's instructions. Conversion to cDNA was performed using Superscript II (Invitrogen, USA) from $3 \mathrm{~g}$ of RNA. RT-PCR was performed using the 


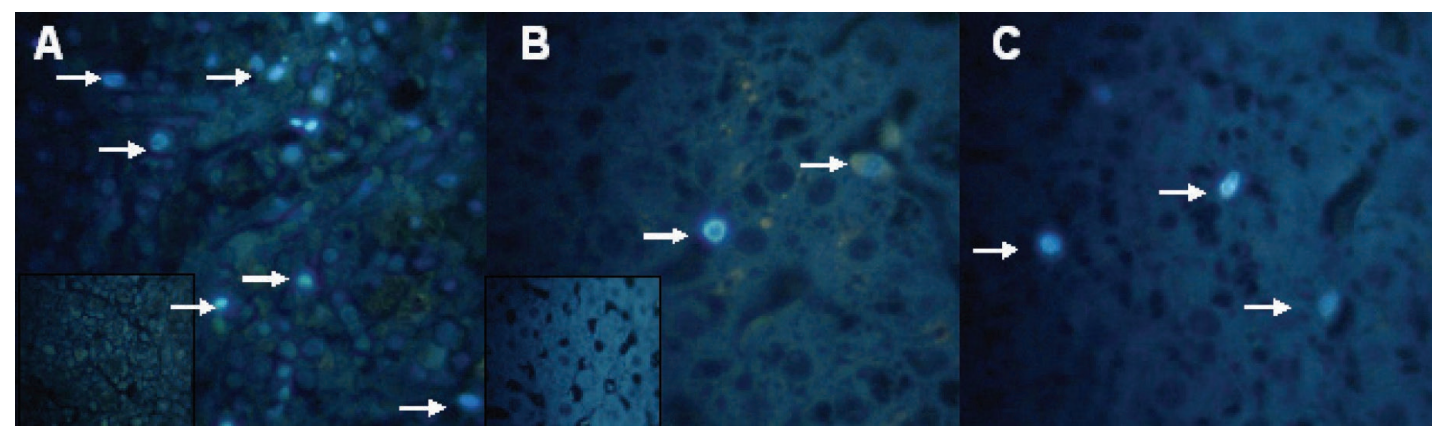

FIGURE 1. DAPI-positive cells (arrows) in spleen (A) and liver (B) of animals injected into the spleen or into the portal vein $(\mathrm{C})$. Insets: DAPI negative images

following primers at $42^{\circ} \mathrm{C}$ for 40 cycles (for 5' TTGTATGAATATGCAAGAAG 3', rev 5' CACTCTTCCCAGGTTTCTTG 3'). PCR products were visualized in $1.5 \%$ agarose gel stained with ethidium bromide. RNA extracted from liver samples was used as positive control.

Gapdh was used as positive internal control both for RT-PCR and PCR reactions. Primers for Gapdh were: for 5' CAGCAATGCATCCTGCAC 3', rev 5' GAGTTGCTGTTGAAGTCACAGG 3').

\section{Statistics}

Statistics was performed using SPSS 12.0 (Statistical Package for Social Science). ALT levels were expressed as the median \pm quartiles. Differences in ALT levels were assessed using Friedman's test.

\section{RESULTS}

\section{APAP-induced hepatotoxicity model}

At day 1, ALT levels increased with statistical significance in all 44 animals by Friedman's test $(P<0.0001)$. At day 3 , ALT levels returned to basal values in all groups, without difference among the groups (Table 1).

TABLE 1. Median and range of ALT levels in rats submitted to APAPinduced hepatotoxicity

\begin{tabular}{lccc}
\hline $\begin{array}{c}\text { Group } \\
\text { (n) }\end{array}$ & 0 & Time (days) \\
\hline PV-H & $42.0(37.0-54.0)$ & $267.0(140-543.8)$ & $43.5(34.0-62.0)$ \\
PVPBS & $36.0(32.0-43.0)$ & $130.0(103.0-215.0)$ & $39.0(27.0-51.0)$ \\
SPL-H & $57.5(49.8-61.0)$ & $197.5(102.8-403.8)$ & $38.5(34.0-61.8)$ \\
SPL-PBS & $43.5(35.3-47.0)$ & $158.0(84.03-02.0)$ & $31.0(28.0-34.0)$ \\
\hline
\end{tabular}

*Values at day 1 are statistically different from days 0 and 3 for all groups (Friedman's test, $P<0.0001)$ but not among groups at any time point

\section{Hepatocyte transplantation and survival analysis}

Hepatocytes were isolated from male Wistar rats' livers weighing from $15 \mathrm{~g}$ to $20 \mathrm{~g}$. The number of isolated hepatocytes ranged between $2.54 \times 10^{7}$ cells $/ \mathrm{mL}$ and $2.22 \times 10^{8}$ cells $/ \mathrm{mL}$. Viability of hepatocytes was $>90 \%$ by trypan's blue exclusion test, and $1 \times 10^{7}$ hepatocytes were transplanted.

Survival analyses showed that 39 animals survived until the end of experiment (day 3 ). All animals that received he-

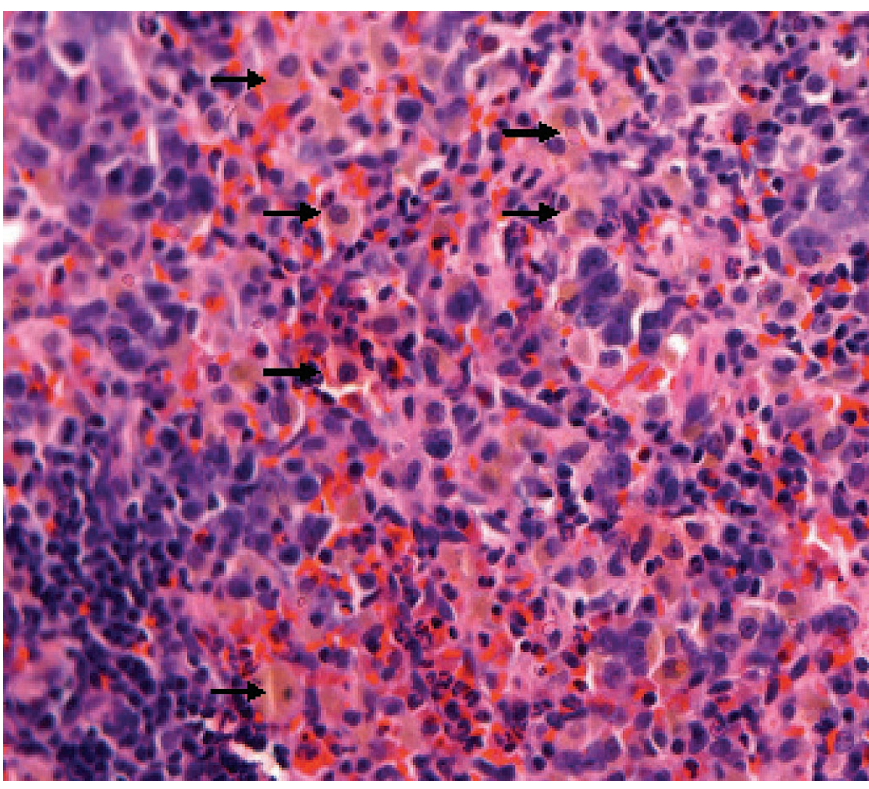

FIGURE 2. H-E staining of the spleen, showing scattered hepatocytes (arrows), magnification $40 \mathrm{X}$

patocytes (groups PV and SPL) survived until day 3, however five rats that received PBS through the portal vein died, three on day 1 and two on day 2 .

\section{Histology}

The presence of transplanted cells was determined by DAPI-staining prior to injection. The number of DAPI-positive hepatocytes in the liver of animals injected through the portal vein ranged from 12 to 130 , with a mean of $61.2 \pm$ 44.6 stained cells per animal. In animals injected through the spleen, the number of DAPI-positive hepatocytes in the liver ranged from 0 to 81 , with a mean of $50.0 \pm 31.8$ stained cells per animal. In these animals, the number of DAPI-positive hepatocytes in the spleen ranged from 75 to 414 , with a mean of $166.2 \pm 127.3$ stained cells per animal. The presence of hepatocytes in spleen was also visualized on H-E slides (Figures 1 and 2).

\section{Molecular analysis}

The engraftment of hepatocytes at day 3 in liver and spleen by PCR analysis for Y-chromosome gene (Sry) in 
female recipient organs was investigated. Sry was positive in livers or spleens from animals injected through the portal vein or into the spleen.

In order to determine if spleen transplanted hepatocytes remained functional albumin expression was analyzed in the spleen of eight animals from group SPL-H. Albumin expression by RT-PCR was not detected in any animal, although all of them were positive for Gapdh and liver samples used for positive control were also positive.

\section{DISCUSSION}

Hepatocyte transplantation presents many advantages over OLT. For instance, cells from a single liver donor can be used by many recipients ${ }^{(8)}$. In our experience, a male donor rat could provide fresh hepatocytes for at least 10 female recipients. Freshly isolated hepatocytes have been shown to perform better than cryopreserved cells in many studies $^{(4,10)}$, and hepatocytes are known to be very sensitive to freezing damage, decreasing their attachment efficiency and engraftment ${ }^{(28)}$. Therefore, this study aimed to test fresh hepatocyte transplantation in a rat model of APAP-induced hepatotoxicity.

In APAP-induced hepatotoxicity in humans, ALT levels start to increase from day 1 , peak at day 3 and start to decrease at day $4^{(22)}$. In our study, animals had the ALT levels peak at day 1 , started to decrease at day 2 and had returned to basal values at day 3 . Lee et al. ${ }^{(12)}$, analyzing 1,147 cases of APAP-induced ALF in humans demonstrated that ALT levels are very high $(2,138$ to 6,731). However, in APAP-induced hepatotoxicity in rats ALT levels are lower in comparison with humans, around of $256.5 \pm 11.2^{(23)}$. That finding is similar to our results, 188.5 (116.7-330.7) at day 1, using a single dose of APAP $1 \mathrm{~g} / \mathrm{kg}$ i.p.. Even though, high mortality rates were not observed and no signs of extensive liver damage were seen by ALT or histology on day 3 .

Hepatocytes can be transplanted directly into the liver or through the portal vein and in the spleen pulp. Although the optimal site for hepatocyte infusion and settlement has not yet been determined, the liver seems to be the natural home of transplanted hepatocytes ${ }^{(13)}$. The spleen is currently the most widely used recipient site for hepatocyte infusion because of its accessibility. Although separated from the portal blood flow, donor hepatocytes transplanted into the spleen have been shown to migrate to other organs, particularly to the host liver ${ }^{(26)}$. Whether the number of engrafted cells in the spleen and their metabolic capacity will be sufficient remains an open question ${ }^{(17)}$.

In this study, the engraftment of hepatocytes in liver and spleen was investigated by PCR analysis for Y-chromosome gene (Sry) in female recipient organs and staining the transplanted cells with DAPI. In all hepatocyte transplantation groups, Sry was positive in liver tissue. This shows that hepatocytes transplanted into the spleen have migrated to the host liver, a finding that is also supported by DAPI-positive hepatocytes in the liver from six animals transplanted into the spleen.

No differences were found in the number of DAPI-positive hepatocytes in the liver of animals injected into the portal vein or into the spleen. This lack of difference in the number of DAPI-positive cells is not easily explained. One would assume that the liver of rats injected through the portal vein would present a greater number of hepatocytes, however some studies suggest that a space for cell engraftment is necessary in the recipient ${ }^{(26)}$. In this study partial hepatectomy or hepatic irradiation were not performed, and maybe the number of dead cells at the time of injection was not sufficient to create a permissive environment for hepatocyte engraftment. Nevertheless, these animals had some degree of lesion, as hepatocytes did remain in the spleen, and it has been suggested that this is required for the establishment of transplanted hepatocytes in rat spleens ${ }^{(20)}$.

A second point to be considered for spleen hepatocyte injection is whether they remain functioning in the spleen. Shibata et al. ${ }^{(26)}$ showed signals of Y-chromosome detectable in the spleen and spleen-resident hepatocytes expressing albumin 12 weeks after intrasplenic transplantation of freshly isolated hepatocytes in rats. In the data presented here, even though Sry was positive in spleen, albumin expression was not detected in a subgroup of eight animals injected into the spleen. One possible explanation for this finding is that, as fresh hepatocytes have a scattered pattern of distribution within the spleen ${ }^{(26)}$, when spleen samples were collected for RT-PCR for albumin expression, hepatocytes could have been lost. On the other hand, the hypothesis that hepatocytes in the spleen underwent a dedifferentiation process caused by the loss of intercellular contact with neighbouring host cells, decreasing specific hepatocyte genes transcription ${ }^{(16)}$, cannot be ruled out.

In conclusion, data presented here shows the feasibility and efficacy of hepatocyte transplantation in the liver or spleen in a mild APAP-induced hepatotoxicity model.

\section{ACKNOWLEDGMENTS}

We thank Sandra Maria Gonçalves Vieira and Jorge Luiz dos Santos for reviewing the manuscript. We also thank Marta Cioato and the team of the Experimental Animal Unit at HCPA for their assistance. This work was supported by FIPE-HCPA. 
Rodrigues D, Silveira TR, Matte U; Grupo de Estudos de Hepatologia Experimental. Transplante de hepatócitos recém-isolados em um modelo de hepatotoxicidade induzida por acetaminofeno em ratos. Arq Gastroenterol. 2012,49(4):291-5.

RESUMO - Contexto - O transplante de hepatócitos é uma modalidade terapêutica atrativa para doenças hepáticas como alternativa ao transplante hepático ortotópico. Objetivo - Investigar a factibilidade do uso de hepatócitos frescos isolados de ratos em um modelo de hepatotoxicidade induzida por paracetamol. Métodos - Hepatócitos foram isolados de ratos Wistar machos e transplantados 24 horas após a administração de paracetamol em receptores fêmeas. As ratas receberam $1 \times 10^{7}$ hepatócitos ou tampão salina fosfato pela veia porta ou no baço e foram sacrificadas após 48 horas. Resultados - Os níveis de alanina aminotransferase medidos durante o experimento não diferiram entre os grupos em nenhum momento. Análises moleculares e histológicas demonstraram a presença de hepatócitos no fígado dos animais transplantados pelo baço ou pela veia porta. Conclusão - Os dados indicam a factibilidade e eficácia do transplante de hepatócitos no fígado ou baço em um modelo de hepatotoxicidade leve induzida por paracetamol.

DESCRITORES - Hepatócitos, transplante. Acetaminofeno. Doença hepática induzida por drogas. Ratos.

\section{REFERENCES}

1. Baldo G, Giugliani R, Uribe C, Belardinelli MC, Duarte ME, Meurer L, da Silveira TR, Matte U. Bone marrow mononuclear cell transplantation improves survival and induces hepatocyte proliferation in rats after $\mathrm{CCl}(4)$ acute liver damage. Dig Dis Sci. 2010;55:3384-92.

2. Belardinelli MC, Pereira F, Baldo G, Vicente Tavares AM, Kieling CO, da Silveira TR, Meurer L, Soares Duarte ME, Giugliani R, Matte U. Adult derived mononuclear bone marrow cells improve survival in a model of acetaminophen-induced acute liver failure in rats. Toxicology. 2008;247:1-5.

3. Chedrawy EG, Wang JS, Nguyen DM, Shum-Tim D, Chiu RC. Incorporation and integration of implanted myogenic and stem cells into native myocardial fibers: anatomic basis for functional improvements. J Thorac Cardiovasc Surg. 2002; 124:584-90.

4. David P, Alexandre E, Audet M, Chenard-Neu MP, Wolf P, Jaeck D, Azimzadeh A, Richert L. Engraftment and albumin production of intrasplenically transplanted rat hepatocytes (Sprague-Dawley), freshly isolated versus cryopreserved, into Nagase analbuminemic rats (NAR). Cell Transplant. 2001;10:67-80.

5. Dhawan A, Mitry RR, Hughes RD, Lehec S, Terry C, Bansal S, Arya R, Wade JJ, Verma A, Heaton ND, Rela M, Mieli-Vergani G. Hepatocyte transplantation for inherited factor VII deficiency. Transplantation. 2004;78:1812-4.

6. Dhawan A, Mitry RR, Hughes RD. Hepatocyte transplantation for liver-based metabolic disorders. J Inherit Metab Dis. 2006;29:431-5.

7. Fox IJ, Chowdhury JR, Kaufman SS, Goertzen TC, Chowdhury NR, Warkentin PI, Dorko K, Sauter BV, Strom SC. Treatment of the Crigler-Najjar syndrome type I with hepatocyte transplantation. N Engl J Med. 1998;338:1422-6.

8. Grompe M, Laconi E, Shafritz DA. Principles of therapeutic liver repopulation. Semin Liver Dis. 1999;19:7-14.

9. Horslen SP, McCowan TC, Goertzen TC, Warkentin PI, Cai HB, Strom SC, Fox IJ. Isolated hepatocyte transplantation in an infant with a severe urea cycle disorder. Pediatrics. 2003;111:1262-7.

10. Jamal HZ, Weglarz TC, Sandgren EP. Cryopreserved mouse hepatocyte retain regenerative capacity in vivo. Gastroenterology. 2000;118:390-4.

11. Kaplowitz N. Acetaminophen hepatoxicity: what do we know, what don't we know, and what do we do next? Hepatology. 2004;40:23-6.

12. Lee WM, Squires RH Jr, Nyberg SL, Doo E, Hoofnagle JH. Acute liver failure: summary of a workshop. Hepatology. 2008;47:1401-15.

13. Michalopoulos GK. Liver regeneration: molecular mechanisms of growth control FASEB J. 1990;4:176-87

14. Mitry RR, Dhawan A, Hughes RD, Bansal S, Lehec S, Terry C, Heaton ND, Karani JB, Mieli-Vergani G, Rela M. One liver, three recipients-segment. IV from split-liver procedures as a source of hepatocytes for cell transplantation. Transplantation. 2004;77:1614-6.
15. Muraca M, Gerunda G, Neri D, Vilei MT, Granato A, Feltracco P, Meroni M, Giron G, Burlina AB. Hepatocyte transplantation as a treatment for glycogen storage disease type 1a. Lancet. 2002;359:317-8.

16. Nicoluzzi JEL, Repka JCD, Rocha LCA, Campos ACL, Caron PE, Parc R Assessment of bioartificial liver using human hepatocytes immunoprotected by macroencapsulation. Rev Col Bras Cir. 2004;31:311-7.

17. Nussler A, Konig S, Ott M, Sokal E, Christ B, Thasler W, Brulport M, Gabelein G, Schormann W, Schulze M, Ellis E, Kraemer M, Nocken F, Fleig W, Manns M, Strom SC, Hengstler JG. Present status and perspectives of cell-based therapies for liver disease. J Hepatol. 2006;45:144-59.

18. O'Grady JG. Acute liver failure. Postgrad Med J. 2005;81:148-54

19. Polson J, Lee WM; American Association for the Study of Liver Disease. AASLD position paper: the management of acute liver failure. Hepatology. 2005;41:1179-97.

20. Ponder KP, Gupta S, Leland F, Darlington G, Finegold M, Demayo J, Ledley FD, Chowdhury JR, Woo SLC. Mouse hepatocytes migrate to liver parenchyma and function indefinitely after intransplenic transplantation. Proc Natl Acad Sci USA. 1991;88:1217-21.

21. Reid AB, Kurten RC, McCullough SS, Brock RW, Hinson JA. Mechanisms of acetaminophen-induced hepatotoxicity: role of oxidative stress and mitochondrial permeability transition in freshly isolated mouse hepatocytes. J Pharmacol Exp Ther. 2005;312:509-16

22. Rumack BH. Acetaminophen misconceptions. Hepatology. 2004;40:10-5.

23. Salam OMEA, Baiuomy AR, El-Shenawy SM, Hassan NS. Effect of pentoxifylline on hepatic injury caused in the rat by the administration of carbon tetrachloride or acetaminophen. Pharmacol Res. 2005;57:596-603.

24. Sass DA, Shakil AO. Fulminant hepatic failure. Liver Transpl. 2005;11:594-605.

25. Seglen PO. Preparation of isolated rat liver cells. Methods Cell Biol. 1976;13:2983.

26. Shibata C, Mizuguchi T, Kikkawa Y, Nobuoka T, Oshima H, Kawasaki H, Kawamoto M, Katsuramaki T, Mitaka T, Hirata K. Liver repopulation and long-term function of rat small hepatocyte transplantation as an alternative cell source for hepatocyte transplantation. Liver Transpl. 2006;12:78-87.

27. Smets F, Najimi M SF, Sokal EM. Cell transplantation in the treatment of liver diseases. Pediatr Transplant. 2008;12:6-13.

28. Terry C, Dhawan A, Mitry RR, Hughes RD. Cryopreservation of isolated human hepatocytes for transplantation: state of the art. Cryobiology. 2006;53:149-59.

Received 12/7/2012 Accepted 24/8/2012. 